\title{
The Predictive Factors of Abnormal Esophageal Motility in Systemic Sclerosis Patients by High Resolution Manometry
}

\author{
ESSAM ABD EL-MOHSEN, M.D.* and RANIA M. GAMAL, M.D.** \\ The Departments of Internal Medicine* and Rheumatology \& Rehabilitation**, Faculty of Medicine, Assiut University, \\ Assiut, Egypt
}

\begin{abstract}
Background: Esophageal motility changes occur in about $80 \%$ of systemic sclerosis (SSc) patients with decreasing the motility of the lower two-thirds of the esophagus and lower esophageal sphincter (LES) pressure.
\end{abstract}

Aim of Study: Using high resolution manometry (HRM) to study the esophageal motility disorder in patients with systemic sclerosis to evaluate the predictive factors associated with esophageal affection.

Patients and Methods: A prospective study was done on twenty female patients with SSc. Demographic data and esophageal symptoms including Gastroesophageal Reflux disease (GERD) and dysphagia were evaluated. All patients underwent HRM and High Resolution Computed Tomography (HRCT), Erythrocyte sedimentation rate (ESR), C-reactive protein (CRP), Hemoglobin level (Hgb), Forced Vital Capacity (FVC).

Results: High resolution manometry showed normal upper esophageal contraction in $100 \%$ of patients. Middle and lower esophageal contraction were normal in $30 \%$, hypoperestalsis in $5 \%$, and aperestalsis in $65 \%$ of patients. Regarding the lower esophageal sphincter pressure, it showed normal pressure in $30 \%$, hypotensive in $65 \%$ and hypertensive in $5 \%$ of patients. The esophageal involvement was GERD in $70 \%$ and dysphagia in $45 \%$ of patients. The pulmonary involvement was dyspnea in $70 \%$ and cough in $40 \%$ of patients. All patients had skin involvement. Abnormal motility was present in 14 out of 20 patients $(70 \%)$ which was significantly related to Interstitial Lung Disease (SSc-ILD) ( $p=0.001)$, SSc subtypes $(p=0.03)$, dyspnea $(p=0.01)$ and FVC $(p=0.046)$. A significant relation between GERD and ILD $(p<0.05)$ was found.

Conclusion: This study confirmed an increased prevalence of esophageal motility disorders in SSc patients with and without esophageal symptoms.

Key Words: HRM - Systemic sclerosis - HRCT - Esophageal motility.

\section{Introduction}

SYSTEMIC sclerosis $(\mathrm{SSc})$ is a generalized disease affecting the connective tissue of skin, gastrointestinal tract, lungs, kidneys and heart. There is massive deposition of the collagen, alterations of the

Correspondence to: Dr. Essam Abd El-Mohsen, E-Mail: essam 223@yahoo.com microvasculature and disturbances of the immune system [1] . Pulmonary hypertension, progressive pulmonary fibrosis, severe gastrointestinal involvement, and heart disease related to systemic sclerosis are the main causes of death. Limited disease has a relatively better prognosis except when pulmonary hypertension develops as a late complication [2] The annual incidence of systemic sclerosis is estimated to be 10 to 20 cases per 1 million persons [3] .

Its aetiology is unknown, occurring most frequently in females, aged 35-65 years. It is classified as diffuse cutaneous systemic sclerosis $(\mathrm{dcSSc})$ or limited cutaneous systemic sclerosis ( $1 \mathrm{cSSc}$ ) based on the extent of cutaneous involvement [4]. The lcSSc patients may have skin thickening which involves the extremities distal to the knees and elbows. In contrast, dcSSc have skin thickening involving the trunk and/or limbs proximal to the knees and elbows [5].The collaboration of the American College of Rheumatology and the European League Against Rheumatism (EULAR) proposed a new set of criteria in 2013. Further items are given a weighted score, a score of 9 or more is diagnostic of systemic sclerosis. A score of 9 is given for the major criterion of skin thickening extending proximal to the metacarpophalangeal (MCP) joints, therefore is sufficient to make a diagnosis on its own [6].

Gastrointestinal tract involvement is very common, affecting about $90 \%$ of the systemic sclerosis patients [7]. It is commonly affecting the esophagus. The incidence of subjective esophageal symptoms (reflux and/or dysphagia) ranges from $42-80 \%$, and as many as $50-90 \%$ of patients with SSc have abnormalities on esophageal motility. Thus, the esophagus is second to the skin as the most commonly affected organ in SSc [8-10]. The gastroesophageal reflux (GER) is suggested to be an important cause of interstitial lung disease (SScILD) and idiopathic pulmonary fibrosis [11] . 
An esophageal motility pattern consisting of distal aperistalsis and a hypotensive lower esophageal sphincter (LES) is often termed scleroderma esophagus; however, this pattern can be identified in other systemic diseases [12]. Despite its prevalence, the understanding of the pathogenesis of esophageal dysfunction in SSc remains relatively poor; mechanisms involving neurodegeneration, vascular injury, ischemia and collagen deposition causing muscular atrophy and fibrosis are considered [13]

Late manifestation of SSc-related lung disease is dyspnea; however, lung involvement is common and is the leading cause of death in patients with systemic sclerosis [14]. Systemic sclerosis can cause affection of the lung parenchyma in the form of interstitial lung disease and the pulmonary blood vessels in the form of pulmonary arterial hypertension. Thus, for the early detection of interstitial lung disease and pulmonary arterial hypertension, a routine screening in all patients using pulmonary function tests and Doppler echocardiography is necessary $[15,16]$.

Symptoms are poorly correlated with objective findings of esophageal disease in patients with SSc [17]. So this study was conducted to detect the relation between the esophageal symptoms and the findings of esophageal motility to accomplish early and effective management.

\section{Patients and Methods}

This study included 20 patients with a definite diagnosis of SSc. Patients attended the Department of Internal Medicine, Assiut University Hospital (Motility Unit), during the period from March 2014 to October 2015. Full history, clinical evaluation, laboratory investigations; Erythrocyte sedimentation rate (ESR), C-reactive protein (CRP) and Hemoglobin level $(\mathrm{Hgb})$, high resolution CT chest and pulmonary function test were done. The patients were all females and their age ranged 19-60 years with mean age $39.7 \pm 14.4$ and their disease duration range was considered from the onset of Raynaud's phenomena. The criteria for diagnosis of SSc were based on the American college of rheumatology and EULAR new classification criteria for SSc [6] Patients were grouped according to LeRoy and Medsger (2001) Criteria for SSc [5]. They were grouped into 2 groups; 7 patients (35\%) had diffuse SSc (dcSSc) and 13 patients (65\%) had limited cutaneous SSc (lcSSc). Modified Rodnan Skin Score (MRSS), to measure dermal skin thickness based on 17 body parts, scored 0-51 [18].
They underwent high resolution manometry assessment to the esophageal motility to evaluate if there was difference between the two groups. The data of the swallows were recorded and evaluated for each patient and compared to the other parameters. The exclusion criteria were patients who couldn't withstand the procedure, patients with overlap syndrome, localized form of scleroderma, diabetes or thyroid diseases.

Detailed history was taken from each patient including age, sex, smoking, disease duration, skin manifestation (Raynaud's phenomena, skin tightness), gastrointestinal manifestations in the form of dysphagia, GERD (heart burn and/or regurgitation) and pulmonary manifestations as cough and dyspnea according to New York Heart Association (NYHA) classification.

High resolution manometry was done by a 32channel solid-state catheter with $1 \mathrm{~cm}$ intervals pressure sensors (Medical Measurement Systems, MMS Enschede, Netherlands). The catheter was put in water for zeroing before use. The maneuver was done with the patient in a sitting position. A local anesthetic spray was introduced in the nostril before passing the catheter trans-nasally and the patient was asked to swallow water during its pass then fixed to the nose after correct positioning by the appearance of the LES (lower esophageal sphincter) and UES (upper esophageal sphincter) pressure waves.

The resting pressure of the upper esophageal sphincter and lower esophageal sphincter were recorded first. Then ten swallows of water each $5 \mathrm{ml}$ was taken with 30 seconds apart. All data was stored and analyzed using MMS Database software (MMS, Enschede, Netherlands). The amplitude $(\mathrm{mmHg})$, duration (seconds) and velocity of each contraction were measured, the esophageal body contractions were divided into the proximal third contraction; between the upper esophageal sphincter and the transition zone, the middle one; between the transition zone and the distal trough and the distal one; between the distal trough and the upper border of the LES [19].

Esophageal body motility was classified according to Chicago Classification as normal contraction when $20 \mathrm{mmHg}$ isobaric contour without large or small break, weak contraction as shown in Fig. (1) when large break more than $5 \mathrm{~cm}$ length in the $20 \mathrm{mmHg}$ isobaric contour in more than $20 \%$ of swallows or more than $30 \%$ of swallows with 2$5 \mathrm{~cm}$ break length in the $20 \mathrm{mmHg}$ isobaric contour of the esophagus and aperistalsis as shown in Fig. 
(2) when the esophageal contraction in the smooth muscle part of the esophagus (distal two thirds) were absent. The resting basal pressure of the LES was measured (normally $10-45 \mathrm{mmHg}$ ), when the LES resting pressure was below $10 \mathrm{mmHg}$ a hypotensive LES was considered, and hypertensive LES when the resting LES pressure was more than $45 \mathrm{mmHg}$. The integrated relaxation pressure 4seconds (IRP4s) was measured (normally less than $15 \mathrm{mmHg}$ [20]. The proximal and distal contractile integral (PCI and DCI), the contractile front velocity were assessed for the distal two thirds of the esophagus [19,21]

The pulmonary function test was performed. Forced Vital Capacity (FVC) was done by spirometry according to standard technique and patients were classified into normal $\mathrm{FVC} \geq 80 \%$ of predicted and abnormal FVC as $<80 \%$ of predicted. The High-Resolution Computed Tomography (HRCT) scans were evaluated for the absence or presence of the interstitial lung disease (ILD) according to Goh et al., [22] .

This study was approved by the Ethical Committee of Faculty of Medicine, Assiut University. All patients in this study were informed in a written consent containing the detailed description of the study.

\section{Statistical analysis:}

Statistical analysis of the data was performed using the SPSS software (version 16). Descriptive statistics: Mean, standard deviation and percentages were calculated. Student $t$-test was used to compare the mean difference between the two groups and Chi-square test was used to compare the difference in proportion between the two groups. A significant $p$-value was considered when it is $<0.05$.

\section{Results}

Twenty non-smoker female patients (mean \pm SD 39.7 \pm 14.4 , range 19-60) were included in this study. The range of the disease duration was 2-18 years $(7.4 \pm 4.6)$. The patients were divided into 2 subtypes; limited SSc (13 patients, 65\%) and diffuse SSc (7 patients, 35\%). Esophageal abnormal motility was present in 14 patients $(70 \%)$. Patients' parameters were described in Table (1).

All patients included in this study had skin involvement. The esophageal involvement was GERD $70 \%$ and dysphagia $45 \%$. The pulmonary involvement was dyspnea $70 \%$ and cough $40 \%$ as shown in Table (2).
Table (1): Distribution of patients' parameters.

\begin{tabular}{|c|c|c|}
\hline Patients' Parameters & No. & $\%$ \\
\hline \multicolumn{3}{|l|}{ Age: } \\
\hline Range & \multicolumn{2}{|c|}{$19-60$ year } \\
\hline Mean \pm SD & \multicolumn{2}{|c|}{$39.7 \pm 14.4$} \\
\hline \multicolumn{3}{|l|}{ Sex: } \\
\hline Male & 0 & 0 \\
\hline Female & 20 & 100 \\
\hline \multicolumn{3}{|l|}{ Smoking: } \\
\hline Yes & 0 & 0 \\
\hline No & 20 & 100 \\
\hline \multicolumn{3}{|l|}{ Disease duration: } \\
\hline Range & \multirow{2}{*}{\multicolumn{2}{|c|}{$\begin{array}{c}2-18 \text { year } \\
7.4 \pm 4.6\end{array}$}} \\
\hline Mean \pm SD & & \\
\hline \multicolumn{3}{|l|}{ Subtype: } \\
\hline Limited & 13 & 65 \\
\hline Diffuse & 7 & 35 \\
\hline \multicolumn{3}{|l|}{ FVC (\% of predicted): } \\
\hline \multicolumn{3}{|l|}{ Mean \pm SD } \\
\hline Normal $\geq 80 \%(90.70 \pm 8.30)$ & 8 & 40 \\
\hline Abnormal $<80 \%(67.66 \pm 5.44)$ & 12 & 60 \\
\hline \multicolumn{3}{|l|}{$C R P:$} \\
\hline Positive & 14 & 70 \\
\hline Negative & 6 & 30 \\
\hline \multicolumn{3}{|l|}{ ESR: } \\
\hline Range (women) & \multicolumn{2}{|c|}{ 0-29 } \\
\hline Mean \pm SD & \multicolumn{2}{|c|}{$42.3 \pm 14.7$} \\
\hline Normal & 2 & 10 \\
\hline Abormal & 18 & 90 \\
\hline \multicolumn{3}{|l|}{$H g b:$} \\
\hline Range (women) & \multicolumn{2}{|c|}{$12-15.5 \mathrm{~g} / \mathrm{dl}$} \\
\hline Mean \pm SD & \multicolumn{2}{|c|}{$11.4 \pm 1.6$} \\
\hline Normal & 8 & 40 \\
\hline Abormal & 12 & 60 \\
\hline \multicolumn{3}{|l|}{ Esophageal motility: } \\
\hline Normal & 6 & 30 \\
\hline Abnormal & 14 & 70 \\
\hline
\end{tabular}

Table (2): Distribution of diseases manifestation.

\begin{tabular}{lll}
\hline Diseases manifestation & No. & $\%$ \\
\hline Skin involvement: & \multicolumn{2}{c}{} \\
$\quad$ Raynaud's phenomena & 20 & 100 \\
$\quad$ Skin tightness & 20 & 100 \\
MRS S/51 & \multicolumn{2}{c}{$9-29$} \\
$\quad$ Range & \multicolumn{2}{c}{$19 \pm 5.8$} \\
$\quad$ Mean \pm SD & \multicolumn{2}{|c}{} \\
Esophageal involvement: & 9 & 45 \\
$\quad$ Dysphagia & 14 & 70 \\
$\quad$ GERD & \multicolumn{2}{|c}{} \\
Pulmonary involvement: & 8 & 40 \\
$\quad$ Cough & 14 & 70 \\
Dyspnea & &
\end{tabular}

MRSS: Modified Rodnan Skin Score 
Esophageal motility pattern by high resolution manometry:

Upper esophageal contraction was normal in $100 \%$ of the patients. Middle and lower esophageal contraction were normal $(30 \%)$, hypoperestalsis $(5 \%)$, and aperestalsis $(65 \%)$. High resolution manometry regarding the lower esophageal sphincter pressure showed normal pressure (30\%), hypotensive $(65 \%)$ and hypertensive $(5 \%)$ as in Table (3).

There was a significant statistical result that esophageal motility is affected by SSc subtypes with $p<0.05$ as shown in Table (4). There was a significant relation $(p<0.01)$ between abnormal esophageal motility disorders and LES pressure abnormalities as described in Table (5).

There was a significant relation between GERD and ILD $(p<0.05)$ as shown in Table (6). Abnormal motility was found in patients with ILD $(p=0.001)$ dSSc $(p<0.05)$, abnormal FVC $(p<0.05)$, dyspnea $(p<0.01)$ and dysphagia $(p<0.01)$. While no significant relation was found regarding GERD, cough, CRP, ESR and Hgb level as summarized in Table $\left({ }^{7}\right)$.

Table (3): Patterns of esophageal motility by High Resolution Manometry in SSc patients.

\begin{tabular}{|c|c|c|c|c|c|c|c|c|}
\hline \multirow{2}{*}{$\begin{array}{l}\text { Motility } \\
\text { patterns }\end{array}$} & \multicolumn{4}{|c|}{ LES pressure } & \multicolumn{4}{|c|}{ Body peristalsis } \\
\hline & Normal & Hypotensive & Hypertensive & $p$-value & Normal & Hypoperistalsis & Aperistalsis & $p$-value \\
\hline Normal & $6(30 \%)$ & 0 & 0 & 0.003 & $6(30 \%)$ & 0 & 0 & $<0.01$ \\
\hline Abnormal & 0 & $13(65 \%)$ & $1(5 \%)$ & & 0 & $1(5 \%)$ & $13(65 \%)$ & \\
\hline
\end{tabular}

Significant $p$-value $<0.05$

Table (4): HRM findings in SSc patients with and without esophageal symptoms.

\begin{tabular}{|c|c|c|c|c|c|c|c|c|}
\hline & \multicolumn{4}{|c|}{ LES pressure } & \multicolumn{4}{|c|}{ Body peristalsis } \\
\hline & Normal & Hypotensive & Hypertensive & $p$-value & Normal & Hypoperistalsis & Aperistalsis & $p$-value \\
\hline \multicolumn{9}{|c|}{ Systemic Sclerosis: } \\
\hline Limited & 6 & 6 & 1 & $<0.05$ & 6 & 1 & 6 & $<0.05$ \\
\hline Diffuse & 0 & 7 & 0 & & 0 & 0 & 7 & \\
\hline \multicolumn{9}{|l|}{ Dysphagia: } \\
\hline Yes & 0 & 8 & 1 & 0.022 & 0 & 1 & 8 & 0.022 \\
\hline No & 6 & 5 & 0 & & 6 & 0 & 5 & \\
\hline \multicolumn{9}{|l|}{ GERD: } \\
\hline Yes & 3 & 11 & 0 & 0.09 & 3 & 0 & 11 & 0.09 \\
\hline No & 3 & 2 & 1 & & 3 & 1 & 2 & \\
\hline
\end{tabular}

Significant $p$-value $<0.05 \quad$ LES: Lower Esophageal Sphincter.

Table (5): Relation between LES pressure and esophageal body contraction in SSc patients.

\begin{tabular}{lcccc}
\hline & \multicolumn{2}{c}{ Lower Esophageal Sphincter pressure } & \\
\cline { 2 - 4 } $\begin{array}{l}\text { Middle and lower } \\
\text { esophageal contraction }\end{array}$ & $\begin{array}{c}\text { Normal } \\
\text { No. }\end{array}$ & $\begin{array}{c}\text { Hypotensive } \\
\text { No. }\end{array}$ & $\begin{array}{c}\text { Hypotensive } \\
\text { No. }\end{array}$ & $p$-value \\
\hline Normal & 6 & 0 & 0 & \\
Hypoperistalsis & 0 & 0 & 1 & $<0.01$ \\
Aperistalsis & 0 & 13 & 0 & \\
\hline
\end{tabular}

Significant $p$-value $<0.05$. 
Table (6): Relation between ILD and the associated GERD in $\mathrm{SSc}$ patients.

\begin{tabular}{|c|c|c|c|c|c|}
\hline \multirow{3}{*}{ GERD } & \multicolumn{4}{|c|}{ ILD } & \multirow{3}{*}{$p$-value } \\
\hline & \multicolumn{2}{|c|}{ Yes } & \multicolumn{2}{|c|}{ No } & \\
\hline & No. & $\%$ & No. & $\%$ & \\
\hline Yes & 13 & 85 & 1 & 25 & $<0.05$ \\
\hline No & 3 & 15 & 3 & 75 & \\
\hline
\end{tabular}

Significant $p$-value $<0.05 . \quad$ ILD: Interstitial lung disease.

Table (7): Predictive parameters for abnormal esophageal motility in SSc patients.

\begin{tabular}{|c|c|c|c|c|c|}
\hline & \multicolumn{2}{|c|}{$\begin{array}{c}\text { Abnormal } \\
\text { Motility }\end{array}$} & \multicolumn{2}{|c|}{$\begin{array}{l}\text { Normal } \\
\text { Motility }\end{array}$} & \multirow[t]{2}{*}{$\begin{array}{c}p- \\
\text { value }\end{array}$} \\
\hline & No. 14 & $\%$ & No. 6 & $\%$ & \\
\hline \multicolumn{6}{|l|}{ ILD by HRCT: } \\
\hline Yes & 14 & 100 & 2 & 33.33 & 0.001 \\
\hline No & 0 & 0 & 4 & 66.67 & \\
\hline \multicolumn{6}{|l|}{ Dysphagia } \\
\hline Yes & 9 & 64.29 & 0 & 0 & 0.008 \\
\hline No & 5 & 35.71 & 6 & 100 & \\
\hline \multicolumn{6}{|l|}{ GERD: } \\
\hline Yes & 11 & 78.57 & 3 & 50 & 0.201 \\
\hline No & 3 & 21.43 & 3 & 50 & \\
\hline \multicolumn{6}{|l|}{ Cough: } \\
\hline Yes & 6 & 42.86 & 2 & 33.33 & 0.68 \\
\hline No & 8 & 57.14 & 4 & 66.67 & \\
\hline \multicolumn{6}{|l|}{ Dyspnea: } \\
\hline Yes & 14 & 100 & 0 & 0 & $<0.01$ \\
\hline No & 0 & 0 & 6 & 100 & \\
\hline \multicolumn{6}{|l|}{$C R P:$} \\
\hline Positive & 10 & 71.43 & 4 & 66.67 & 0.83 \\
\hline Negative & 4 & 28.57 & 2 & 33.33 & \\
\hline \multicolumn{6}{|l|}{ ESR: } \\
\hline Normal & 2 & 14.29 & 0 & 0 & 0.32 \\
\hline Abnormal & 12 & 85.71 & 6 & 100 & \\
\hline \multicolumn{6}{|l|}{$H g b:$} \\
\hline Normal & 4 & 28.57 & 4 & 66.67 & 0.11 \\
\hline Abnormal & 10 & 71.43 & 2 & 33.33 & \\
\hline \multicolumn{6}{|l|}{$F V C:$} \\
\hline Normal & 2 & 14.29 & 6 & 100 & 0.046 \\
\hline Abnormal & 12 & 85.71 & 0 & 0 & \\
\hline \multicolumn{6}{|l|}{ Systemic } \\
\hline \multicolumn{6}{|l|}{ Sclerosis: } \\
\hline Limited & 7 & 50 & 6 & 100 & $<0.05$ \\
\hline Diffuse & 7 & 50 & 0 & 0 & \\
\hline
\end{tabular}

Significant $p$-value $<0.05$.

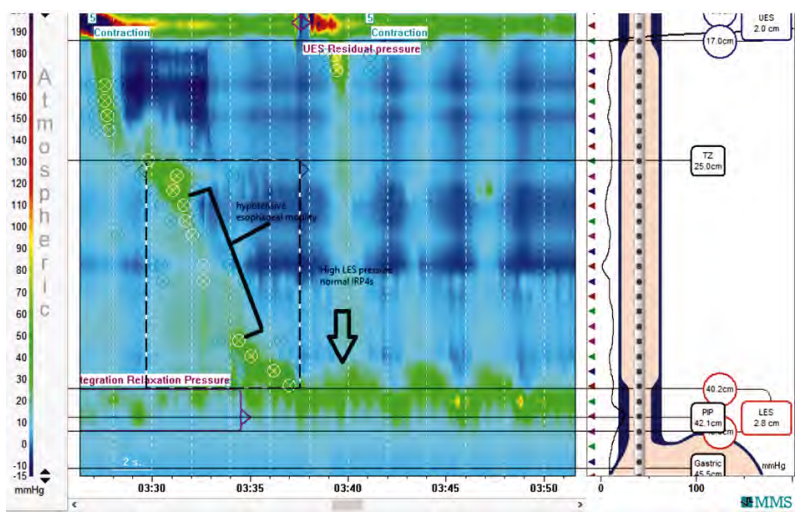

Fig. (1): Hypoperistalsis in the middle and distal esophagus with large break more than $5 \mathrm{~cm}$ length in the $20 \mathrm{mmHg}$ isobaric contour with high LES and normal IRP4s.

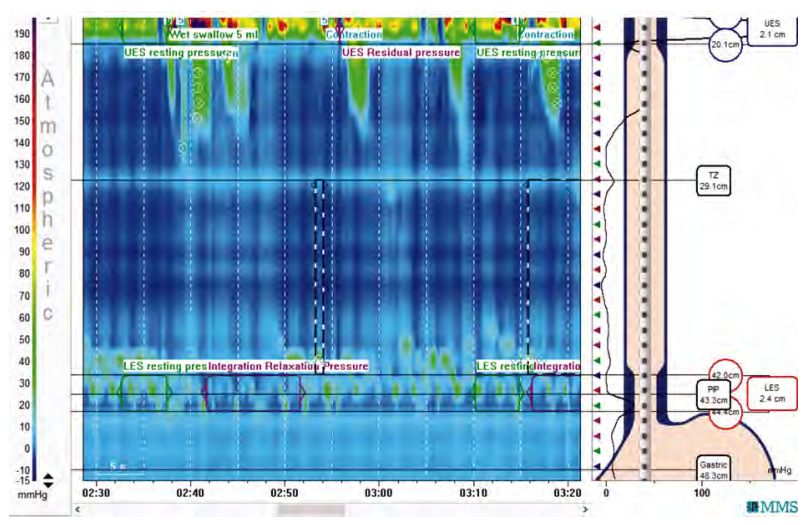

Fig. (2): Aperistalsis in the distal two thirds of the esophagus.

\section{Discussion}

Systemic sclerosis is a chronic systemic autoimmune disease causing hardening of the skin, and affecting the internal organs in more severe cases. Gastrointestinal tract involvement is common in patients with systemic sclerosis [10]. The esophagus is the most commonly affected organ of the gastrointestinal tract in SSc; dysphagia and heart burn are the most common esophageal symptoms [23].

Normal motility was found in 6 patients $(30 \%)$ and the prevalence of esophageal motility disorders was $70 \%$; in the form of hypotensive LES and aperistalsis in 13 patients $(65 \%)$ each, while only one patient showed hypoperistalsis and hypertensive LES resting pressure (5\%). It is noticeable that aperistalsis was more prevalent than hypo peristalsis. Other studies found that the prevalence of esophageal motility disorders ranged from 68.1$81.6 \%$ of patients $[\mathbf{1 , 2 4 , 2 5 , 2 6 ]}$. Thus our obtained results regarding the prevalence of esophageal motility disorders and LES pressure were more or less similar to the mentioned studies. 
It is clear that the most frequent esophageal symptom was GERD, which was present in 70\% of patients. No significant statistical positive relation between the lower esophageal sphincter pressure abnormality, abnormal esophageal motility and the presence of GERD was recorded. Agreed with Roman et al., [17] who found that GERD was in $68.6 \%$ of patients and hypotensive LES and aperistalsis in SSc are common findings in patients with GERD but without a statistical significant value. On the contrary, Sallam et al. and Gemignani et al., $[27,28]$ explained that GERD in SSc could be due to the reduction or absence of LES pressure and esophageal motility disorders.

Roman et al., [17] recorded that dysphagia was not a predictive factor of esophageal dysmotility, in contrary to our results which revealed that dysphagia was present in 9 out of 14 patients with motility disorders (64.29\%) with statistical positive relation ( $p$-value 0.008 ) between the presence of dysphagia and esophageal dysmotility. While 5 of the tested patients with motility disorders didn't complain of dysphagia which could be due to the preservation of the motility of the upper third of the esophagus, the gravity and decreased LES pressure, which led to the passage of the bolus through the esophagus without much resistance.

It was found that the upper esophageal segment contraction was normal in $100 \%$ of the systemic sclerosis patients that have motility disorders. This was in agreement with Yarze et al., [7] who found that normal proximal esophageal contraction pressures were documented in all cases.

Noticeably the lower esophageal sphincter pressure was hypotensive in $65 \%$ of SSc patients which was nearly similar to Lahcene et al., [29] who found a hypotensive LES in $60.8 \%$ of the SSc patients.

Reflux may lead to pulmonary disease via aspiration of gastric contents, and vagal stimulation by acid in the esophagus that causes bronchoconstriction. Conversely, pulmonary disease may exacerbate reflux by increasing inspiratory force, augmenting negative intrathoracic pressure required for ventilation [30]

ILD may be a complication of esophageal motility disorders and associated GERD. The reduced LES pressure in our patients with SSc. with ILD indicates an incompetent antireflux barrier, leading to aspiration of gastric content into the lungs, as reported by Hershcovici et al., [31]. Although the present study doesn't offer direct evidence that aspiration occurred, it suggests that GERD may be one of the predisposing factors, as our patients with severe esophageal motility disorders had higher prevalence of evidence for ILD ( $p-0.001)$, which was in agreement with Savarino et al., [26] who found that the prevalence of ILD was higher in patients with severe esophageal manometric impairment than in patients without esophageal motor disturbances.

Moreover, the relationship between esophageal and lung manifestations may also be due to a concomitant involvement of the internal organs in SSc process, resulting in ILD and fibrosis of esophageal smooth muscle. Confirmed by our results that a significant relation ( $p$-value $<0.05$ ) between the presence of ILD and the associated GERD was found. Similarly, Gilson et al., [11] found that GERD was an important cause of both SSc-ILD and idiopathic pulmonary fibrosis (IPF). Additionally, ILD is a major cause of morbidity and mortality in SSc, aggressive acid-reducing therapy is important in treating reflux to improve pulmonary function [13].

A significant relation between the presence of esophageal dysmotility and pulmonary function abnormalities (FVC) with $p$-value 0.046 was recorded. This was similar to Lock et al., Christmann et al., Airo et al., [32,33,34] who found a reduced lung function as assessed by FVC in patients with absent esophageal contractility, while Marie et al. and Kimmel et al., $[\mathbf{1 , 3 5}]$ found that FVC tended to be lower in SSc patients with severe esophageal manometric involvement, but of no significant value.

Regarding the relation between esophageal motility disorder and SSc subtypes, a significant statistical relation of $p$-value $<0.05$ was found. This was in agreement with Kimmel et al., [35] who found that diffuse skin involvement that correlates with worse prognosis was associated with esophageal dysmotility, in contrary to Savarino et al., [26] who found that disease variant (diffuse vs. limited) were inaccurate predictors of the presence and severity of esophageal involvement.

A significant statistical positive relation between lower esophageal sphincter pressure abnormalities and esophageal body abnormalities in SSc patients was present with $p$-value $<0.01$. Similarly, Roman et al., [17] found that LES and esophageal body abnormalities were associated. A shared pathologic mechanism between skin and esophageal wall thickening could provide insight into the method of esophageal dysfunction in SSc, the presence and composition of esophageal thickening has not been identified on SSc-autopsy studies [36,37] 
Therefore, additional study of well-characterized esophageal function and histology, skin involvement, and symptoms is required.

In conclusion, esophageal involvement is frequent in SSc patients affecting middle and lower parts of the esophagus than upper part. Esophageal dysmotility was present even in patients without symptoms, thus performing HRM in SSc patients with or without esophageal symptoms may benefit for the early detection of esophageal motility disorders in order to reach appropriate treatment of esophageal involvement which may ameliorates symptoms and prevents complications. The association of GERD with SSc-ILD is common, so early management of GERD could postpone the development of SSc-ILD.

\section{References}

1- MARIE I., DOMINIQUE S., LEVESQUE H., DUCROTTE P., DENIS P., HELLOT M.F., et al.: Esophageal involvement and pulmonary manifestations in systemic sclerosis. Arthritis Rheum., 45 (4): 346-54, 2001.

2- MAYES M.D., LACEY J.V.Jr., BEEBE-DIMMER J., et al.: Prevalence, incidence, survival, and disease characteristics of systemic sclerosis in a large US Population. Arthritis Rheum., 48: 2246-2255, 2003.

3- SILMAN A.J., HOCHBERG M.C., COOPER C., et al.: Epidemiology of the Rheumatic Diseases. Oxford, U.K.: Oxford University Press, 192, 1993.

4- MAYES M.D.: Scleroderma epidemiology. Rheum. Dis. Clin. North. Am., 29: 239-254, 2003.

5- LEROY E.C. and MEDSGER T.A.: Criteria for the classification of early systemic sclerosis. J. Rheumatol., 28: 1573-1576, 2001.

6- VAN DEN HOOGEN F., KHANNA D., FRANSEN J., JOHNSON S.R., et al.: Classification criteria for systemic sclerosis: an American college of rheumatology/European league 2013 against rheumatism collaborative initiative. Ann. Rheum. Dis., 72 (11): 1747-55, 2013.

7- YARZE J.C., VARGA J., STAMFL D., CASTELL D.O. and JIMENEZ S.A.: Esophageal function in systemic sclerosis: a prospective evaluation of motility and acid reflux in 36 patients. Am. J. Gastroenterol., 88: 870-6, 1993.

8- ABU-SHAKRA M., GUILLEMIN F. and LEE P.: Gastrointestinal manifestations of systemic sclerosis. Seminars in Arthritis and Rheumatism, 24 (1): 29-39, 1994.

9- SJOGREN R.W.: Gastrointestinal motility disorders in scleroderma. Arthritis and rheumatism, 37 (9): 1265-82, 1994.

10- LOCK G., HOLSTEGE A., LANG B. and SCHOLMERICH J.: Gastrointestinal manifestations of progressive systemic sclerosis. The American Journal of Gastroenterology, 92 (5): 763-71, 1997.

11-GILSON M., ZERKAK D., WIPFF J., DUSSER D., DINHXUAN A.T., ABITBOL V., et al.: Prognostic factors for lung function in systemic sclerosis: Prospective study of 105 cases. Eur. Respir. J., 35 (1): 112-7, 2010.

12- SMOUT A. and FOX M.: Weak and absent peristalsis. Neurogastroenterology and motility. The official journal of the European Gastrointestinal Motility Society, 24 (Suppl 1): 40-7, 2012.

13- EBERT E.C.: Esophageal disease in scleroderma. Journal of clinical gastroenterology, 40 (9): 769-75, 2006.

14- STEEN V.D., LUCAS M., FERTIG N. and MEDSGER T.A.Jr.: Pulmonary arterial hypertension and severe pulmonary fibrosis in systemic scelrosis patients with a nucleolar antibody. J. Rheumatol., 34 (11): 2230-2235, 2007.

15- PROUDMAN S.M., STEVENS W.M., SAHHAR J. and CELERMAJER D.: Pulmonary arterial hypertension in systemic sclerosis: the need for early detection and treatment. Intern. Med. J., 37 (7): 485-494, 2007.

16- VAN LAAR J.M., STOLK J. and TYNDALL A.: Scleroderma lung: Pathogenesis, evaluation and current therapy. Drugs, 67 (7): 985-996, 2007.

17- ROMAN S., HOT A., FABIEN N., et al.: Esophageal dysmotility associated with systemic sclerosis: A highresolution manometry study. Diseases of the Esophagus, 24: 299-304, 2011.

18- CLEMENTS P., LACHENBRUCH P., SIEBOLD J., WHITE B., WEINER S., MARTIN R., WEINSTEIN A., WEISMAN M., MAYES M. and COLLIER D.: Inter and intraobserver variability of total skin thickness score (modified Rodnan TSS) in systemic sclerosis. J. Rheumatol., 22 (7):1281-5, 1995.

19- CLOUSE R.E. and STAIANO A.: Topography of normal and high-amplitude esophageal peristalsis. Am. J. Physiol., 265: G1098-107, 1993.

20- PANDOLFINO J.E., FOX M.R., BREDENOORD A.J. and KAHRILAS P.J.: High-resolution manometry in clinical practice: Utilizing pressure topography to classify oesophageal motility abnormalities. Neurogastroenterol. Motil. , 21: 796-806, 2009.

21- GHOSH S.K., PANDOLFINO J.E., ZHANG Q., et al.: Quantifying esophageal peristalsis with high-resolution manometry: A study of 75 asymptomatic volunteers. Am. J. Physiol. Gastrointest. Liver Physiol., G988-97: 290, 2006.

22- GOH N.S., DESAI S.R., VEERARAGHAVAN S., HANSELL D.M., COPLEY S.J., MAHER T.M., et al. Interstitial lung disease in systemic sclerosis: A simple staging system. Am. J. Respir. Crit. Care. Med., 177: 1248-54, 2008.

23- NTOUMAZIOS S.K., VOULGARI P.V., POTSIS K., KOUTIS E., TSIFETAKI N. and ASSIMAKOPOULOS D.A.: Esophageal involvement in scleroderma: gastroesophageal reflux, the common problem. Semin. Arthritis Rheum., 81-173: 36, 2006.

24- ARIF T., MASOOD Q., SINGH J. and HASSAN I.: Assessment of esophageal involvement in systemic sclerosis and morphea (localized scleroderma) by clinical, endoscopic, manometric and $\mathrm{pH}$ metric features: A prospective comparative hospital based study. BMC Gastroenterology, 15: 24, 2015. 
25- LAHCENE M., OUMNIA N., MATOUGUI N., BOUDJELLA M., TEBAIBIA A. and TOUCHENE B.: Esophageal dysmotility in scleroderma: a prospective study of 183 cases. Gastroenterol. Clin. Biol., 33 (6-7): 466-9, 2009.

26- SAVARINO E., MEI F., PARODI A., GHIO M., FURNARI M., GENTILE A., et al.: Gastrointestinal motility disorder assessment in systemic sclerosis. Rheumatology, 52: 1095-100, 2013.

27- SALLAM H., MCNEARNEY T.A. and CHEN J.D.Z.: Systematic review: Pathophysiology and management of gastrointestinal dysmotility in systemic sclerosis (scleroderma). Aliment. Pharmacol. Ther., 23: 691-712, 2006.

28- GEMIGNANI L., SAVARINO V., GHIO M., PARODI A., ZENTILIN P., de BORTOLI N., et al.: Lactulose breath test to assess oro-cecal transit delay and estimate esophageal dysmotility in scleroderma patients. Semin. Arthritis Rheum., 42 (5): 522-9, 2013.

29- LAHCENE M., OUMNIA N., MATOUGUI N., BOUDJELLA M., TEBAIBIA A. and TOUCHENE B.: Esophageal Involvement in Scleroderma: Clinical, Endoscopic, and manometric Features. ISRN Rheumatology, Article ID 325826. 5 pages, 2011.

30- RAGHU G., FREUDENBERGER T.D., YANG S., CUR TIS J.R. SPADA C., HAYES J., SILLERY J.K., POPE C.E. ${ }^{2 n d}$ and PELLEGRINI C.A.: High prevalence of abnormal acid gastro-oesophageal reflux in idiopathic pulmonary fibrosis. Eur. Respir. J., 27: 136-142, 2006.

31- HERSHCOVICI T., JHA L.K., JOHNSON T., GERSON L., STAVE C., MALO J., KNOX K.S., QUAN S. and
FASS R.: Aliment. Pharmacol. Ther., 34 (11-12): 1295305, 2011

32- LOCK G., PFEIFER M., STRAUB R.H., ZEUNER M. and LANG B.: Association of Esophageal Dysfunction and Pulmonary Function Impairment in Systemic Sclerosis. American Journal of Gastroenterology, 93: 341-345, 1998.

33- CHRISTMANN R.B., WELLS A.U., CAPELOZZI V.L. and SILVER R.M.: Gastroesophageal reflux incites interstitial lung disease in systemic sclerosis: Clinical, radiologic, histopathologic, and treatment evidence. Semin. Arthritis Rheum., 40: 241-9, 2010.

34- AIRO P., DELLA CASA D., DANIELI E., MIS SALE G., CATTANEO R. and CESTARI R.: Oesophageal manometry in early and definite systemic sclerosis. Clin. Rheumatol., 24: 370-6, 2005.

35- KIMMEL J.N., CARLSON D.A., HINCHCLIFF M., CARNS M.A., AREN K.A., LEE J. and PANDOLFINO J.E.: The association between systemic sclerosis disease manifestations and esophageal high-resolution manometry parameters. Neurogastroenterol. Motil., 28: 1157-1165, 2016

36- TREACY W.L., BAGGENSTOSS A.H., SLOCUMB C.H. and CODE C.F.: Scleroderma of the esophagus. A correlation of histologic and physiologic findings. Ann. Intern. Med., 59: 351-6, 1963.

37- ROBERTS C.G., HUMMERS L.K., RAVICH W.J., WIGLEY F.M. and HUTCHINS G.M.: A case-control study of the pathology of oesophageal disease in systemic sclerosis (scleroderma). Gut, 55: 1697-703, 2006. 


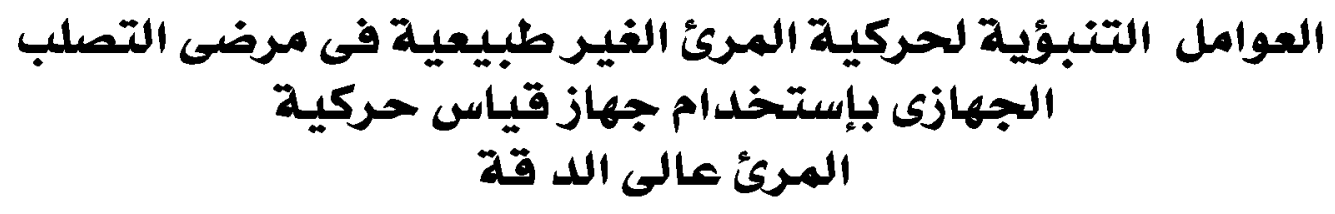

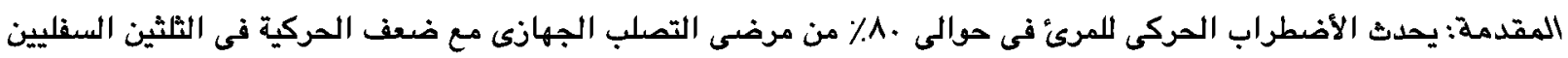

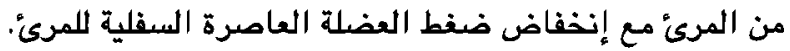

الأهداف: إستخدام جهاز قياس حركية المرى؛ فى مرضى التصلب الجهازى لتقييم العوامل التنبوية المرتبطة بتأثير المرى؛.

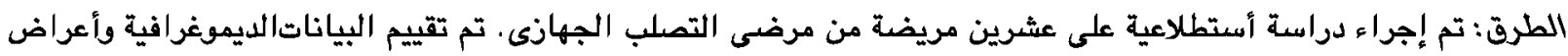

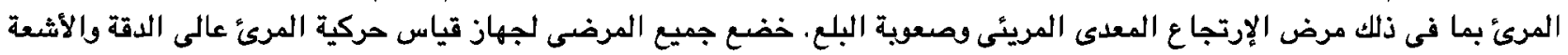
المقطعية عالية الدقة، ومعدل ترسيب كريات الدم الحمراء، ويرتينين سى التفاعلى، ومستوى الهيموجلوبين، والعسعة الحيوية القعرية للرئية. النتائج: أظهر جهاز قياس حركية المرئ عالى الدقة إنقباضاً لعضلة المرئ العلوية فى ـ . 1\% من المرضى. وكان إنقباض عضلة

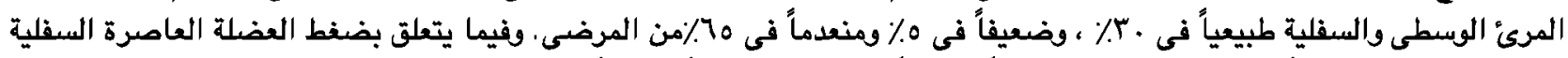

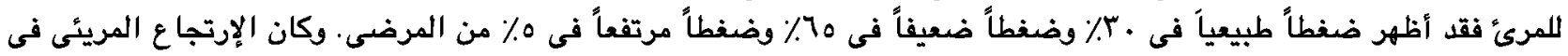

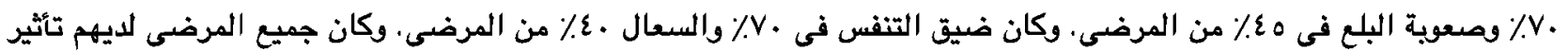

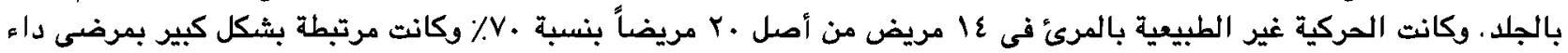

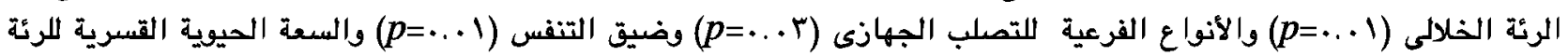

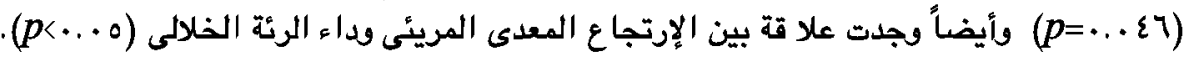
الخلاصهة: أكدت هذه الدرسية زيادة أنتشار أضطرابات حركية المرئ فى مرضى التصلب الجهازى فى وجود وعدم وجود أعراض المرىئ. 